collection that is predominantly modern, and in fields like science and technology where users tend to remember titles of books rather than the author's names.

It is difficult to get meaningful statistics of interlibrary cooperation in the UK because so much is done informally at the local level, and it would be misleading to set up a league table for those libraries which do the most lending. But a recent survey carried out by the Office for Scientific and Technical Information (OSTI) suggests the part played by the NLLST in satisfying requests for loans (Clements, D. W., Journal of Librarianship, 1, 107; April 1969). Out of a total of 3,861 requests for loans in eight local areas in the UK, $1,216(55 \cdot 2$ per cent) were satisfied at the NLLST, and for 95 per cent of these this library was the first location tried. 78 per cent of the requests met by the library were received by the applicants within a week, and 93 per cent within two weeks. There were 209 unsuccessful requests to the NLLST, representing an average failure of about 15 per cent. It is not surprising that the NLLST comes out well in this survey; 85 per cent of loan requests in the survey were in the scientific and technological fields, 62 per cent of the total requests were for periodicals, and where the date of the publication was recorded, 63 per cent of the periodicals required had been published after 1960 ; this is just the literature in which the NLLST specializes.

\section{SCIENCE MUSEUM}

\section{Push Button Science}

The Science Museum in London has a bright and spacious new children's gallery and, although it is not yet completed, most of it has been opened in time for the school holidays. Because a special effort had been made to open before Easter, several exhibits are still in various stages of installation and are not yet working or have no explanatory labels. Nevertheless, the children are turning handles and pressing buttons on familiar as well as new exhibits now housed in the basement of the museum's new extension.

The aspiring Mr Universe can still try his strength on the weights and pulleys and see how different systems require more or less effort. The self-opening door is there too, although it must be much less of a wonder now that public buildings often have this system. The dioramas of lighting and transport through the ages now have their own small darkened galleries with seats for tired adults.

New exhibits include cut-away working models showing how various engines-steam, two-stroke, four-stroke, diesel, Wankel-work, and how electricity is generated. Another new and popular acquisition is the periscope from HM submarine Tiptoe through which can be seen, after patient queuing, the galleries above the basement. A hole in the wall reveals a dark universe with a brightly coloured Earth spinning on its axis, with the Moon speeding round it. The plane of the Moon's orbit continually changes, so that eclipses can be seen frequently. And among all this, looking as if it might have strayed in from the Victoria and Albert Museum nearby, is the highly decorated aeolian organ that Queen Victoria used to play at Balmoral Castle. This gift from the Queen is to be demonstrated every afternoon.

\section{Parliament in Britain}

\section{Vivisection}

Recommendations made by the Littlewood Committee about the setting up of special breeding units outside laboratories for the supply of animals to be used in experiments are under consideration. $\mathrm{Mr}_{\mathrm{r}}$ Merlyn Rees, for the Home Department, said that the expansion of the biological sciences and the mandatory testing of biological substances were the main reasons for the 1.5 million increase in the number of experiments on live animals between 1965 and 1967. In 1967, there were $4,755,680$ experiments, of which 14,962 were on dogs, 14,531 on cats and 471 on horses. (Written answer, March 31.)

\section{Academic Salaries}

THE machinery for negotiating salaries for university lecturers is being discussed by the Department of Education and Science, the Committee of Vice-Chancellors and the Association of University Teachers. Mr Eric Moonman (Billericay) claimed that many university teachers felt that they had had a raw deal in comparison with the awards made to doctors in the tenth report on salaries for doctors and dentists. $\mathrm{Mr}$ Harold Walker, for the Department of Employment and Productivity, said the Prices and Incomes Board would institute a review of university teachers' pay at the appropriate time. (Oral answer, March 31.)

\section{Metrication of Maps}

Mr Kenneth Robinson, Minister for Planning and Land, said the conversion of Ordnance Survey maps to the metric system will cost $£ 3$ million and will be spread over the next fifteen years. On new and revised Ordnance Survey maps at the 1/1,250 and 1/2,500 scales, heights will be shown in metres and areas of parcels of land in hectares as well as acres. The sixinch map will be replaced by a 1/10,000 scale map with metric contours. So far there are no proposals for the conversion of the smaller scale maps. (Written answer, April 1.)

\section{Social Science Research Council}

Mrs Shirley Williams, for the Department of Education and Science, said the expenditure of the Social Science Research Council and the staff complements, for the years ending in March 1966, 1967, 1968 and 1969 were $£ 22,000$ and $15 ; £ 590,000$ and $29 ; £ 870,000$ and 43 ; and $£ 1,470,000$ (estimated) and 84 respectively. (Written answer, April 2.)

\section{Parliamentary Inquiries}

AfTer the Easter recess, the Select Committec on Science and Technology will split into two subcommittees for the remainder of the session to carry out two short investigations, one on the Natural Environment Research Council (NERC) and the other on the reorganization of the British nuclear power industry. Both investigations are expected to take only a few months. Subcommittee E, which is to deal with NERC, starts work on April 16, and subcommittee $D$, on the nuclear power industry, on the following day. The examination of NERC, the first research council to be investigated by the Select Committee, is expected to be the first of a series of inquiries into the workings of the research councils. 